\title{
The Constitutional Transformation and a Threat of the Environment in Poland
}

\author{
Krzysztof R. Mazurski \\ The Wrocław University of Technology, Wrocław, Poland. \\ Email: mazurski@wr.onet.pl \\ Received February $15^{\text {th }}, 2011$; revised March $27^{\text {th }}, 2011$; accepted May $7^{\text {th }}, 2011$.
}

\begin{abstract}
The article concerns a problem of the quantitative seizure of a threat to natural environment. Applied taxonomic method-leading to so called synthetic index of threat and basing on earlier tests, showed the large usefulness for analyses in time and space. Additionally, it was undertaken analysis of connections with economic-political situation in Poland as a result of the constitutional transformation after 1989. It was found that the intensity of anthropic pressure had clearly decreased, but this does not have the statistical relationship with the variable size of inputs for the environment protection.
\end{abstract}

Keywords: Environment, Measures, Threat, Transformation, Poland

\section{Introduction}

The negative influence of industry is generally regarded as a basic factor of negative anthropic pressure on natural environment. The problem has been eased in many countries while remaining a serious concern in some of the largest e.g. China, which develops its industry at heavy environmental cost [1]. Presumably this follows the Marxist idea that such matters are unimportant and the environment has no economic value. So the natural environment has been exploited without concern over negative results [2], but neglect of the such dangers has caused serious problems for many societies.

Events in Poland in 1980 initiated the process which led to the disintegration of the Soviet camp and the commencement of deep transformations regarding the political and economic system. As a result Poland has begun a shaping of a democratic system and a free-market economy since 1989 [3]. Thereby the interesting question appears, whether the transformation-leading a real authority to the society in the system of territorial selfgovernments, contributed to the improvement of the situation within a state of the environment. For that purpose investigations, carried out for the decline of the socialist period in Poland, were used for the trend analysis in the formation of the synthetic indicator of threat- further being cited as SIT, which refers to the natural environment of any particular country.

\section{Research Methodology}

Generally it should be found, that there is a fundamental difficulty over the objective indicators to be applied in order to ensure comparability. The answer indicates quantitative parameters. This brings following matters, as following:

- which features of the threat should be used,

- how to lead to their comparability to the fact of an expression of parameters in different physical units.

Our database has used the published resources of the Polish Statistical Head Office (GUS) available since 1979. In reference to the state of environment one can speak about stimulants and destimulants, with the latter relating to threats. It was necessary to use the same calculation methods and indices to get exactly comparable results. The basic step has included a choosing procedure of such parameters which are conspicuous with a value above the significance level. Weaver's method [4] was applied for that purpose, but after its simplification and making real by K. Doi [5]. Finally some modifications were accepted, introduced by K. Bielecka [6]. This was tied in with an assignment of weights to the parameters appropriate to the relevant locations [7]. The following parameters were used:

- the population density in persons $/ \mathrm{km} 2$,

- the emission of untreated sewage in 0,1 ths. $\mathrm{m} 3 / \mathrm{km} 2$,

- the emission of industrial dusts in thousands $\mathrm{Mg} / \mathrm{km} 2$,

- the emission of industrial gases in thousands $\mathrm{Mg} / \mathrm{km} 2$, 
- the accumulation of industrial waste in thousands $\mathrm{Mg} / \mathrm{km}^{2}$.

Above parameters do not picture the whole of the threat and do not include whole emission of particular factors, for example related to a communication or to a housekeeping. Their use was limited by a set of officially published statistical data and their unbroken series. This was impossible also to state synergic relationships among them, though the statistical correlation factor appears most strongly in reference to the population density, being square with common sense too. The author is conscious also that results of direct observations should be treated too with some caution, as there is a lack of a calibration of many measuring instruments, a manipulation in a data recording, a variable quantity of registered sources of emission and so on [8]. The emission itself is not effective also like a real imission.

The next step has included a use of such statistical method which would be able to make an aggregation of heteronymous parameters. As a choice Hellwig's method was chosen [9]. It relies on the statistical definition of a taxonomic distance between the adopted value-average, median et caetera, and real values from a taken population and a settlement of the final value for this population. Then it behaves to the aggregation of the value for all populations of the data taken into account. The final value is closed in the compartment +1 and -1 -at the regard of destimulants, what is easy for the expression in percentages and helps to interpret the state of threat to natural environment. For the first time Hellwig's method was applied by author for the quantitative evaluation of live conditions in so called areas of the ecological threat - then the abbreviation AET was used, in Poland in 1992 [10]. This has brought interesting and promising results which showed the diverse degree of such threat, and then-different tendencies of a change of the synthetic indicator of threat SIT in time, just in years 1982-1992 [11]. Namely, for example, the fall was shown in the Turoszów AET at $48.53 \%$ down to $39.29 \%$ when the growth in the Legnica AET from $43.74 \%$ down to $51.11 \%$. The indicator renders so both a spatial dynamics, and a time one as well. This has engaged presentings of SIT on the world arena also [12].

\section{Results and Analysis}

Basing on adopted premises it was decided to check, whether a change of the system - called the transformation or transition, has affected a state of threat on Poland's nature. For that purpose the continuation of earlier researches was used. They showed for example that the threat by negative anthropic pressure had increased in years $1986-1989$ from the level $13.72 \%$ up to $14.29 \%$ [13]. For further calculations the same parameters have been used. Results are visible in Figure 1.

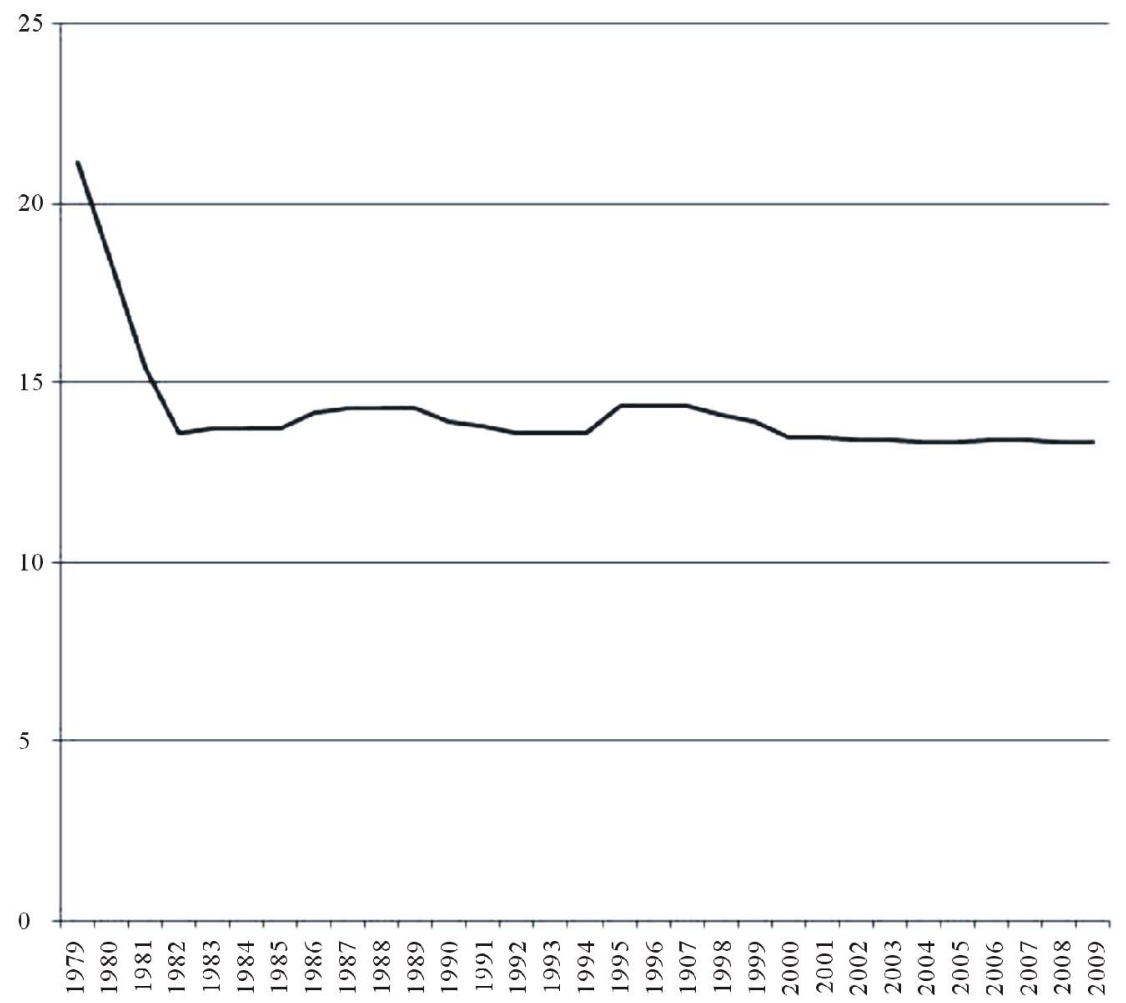

Figure 1. Changes of synthetic index of threat SIT in percentage for Poland during the years 1979-2009. 
It is possible to mark off several characteristic phases with the formation of the SIT value. The first phase shows a rapid decrease until 1982-till about 7.5\%. The explanation stays in the serious economic crisis which was initiated at the end of the 1970s, and with the commencement of the wide strike wave as an expression of the rebellion to the governing party. After its suppression in the way of the war state- being kept since the end of 1981 until mid-1983, the Polish economy increased its efficiency, which meant too the increase of emission of threats to natural environment. This can be called "the last paroxysm of the socialist economy". The next phase - the fall of SIT, was joined with the commencement of the modernization of Polish industry, and with the liquidation of many works. The second half of the 1990s brought new investments and the growth of production, what at once appeared with the following culmination of SIT. The liquidation of outdated technologies and growing protection requirements of the natural environment have led to the reduction of negative anthropic pressure and its stabilization on level lower by about $7.5 \%$ in comparison to 1979. In spite of the revealed culminations of SIT, changes are generally small, because the standard deviation for the period $1979-2009$ amounts only $0.042 \%$. The 2009 SIT implicates following data:

- the population density $122 \mathrm{P} / \mathrm{km} 2$,

- the emission of untreated sewage 4.2 ths. $\mathrm{m} 3 / \mathrm{km} 2$,

- the emission of industrial dusts $1.34 \mathrm{Mg} / \mathrm{km} 2$,

- the emission of industrial gases $10.4 \mathrm{Mg} / \mathrm{km} 2$,
- accumulated industrial waste $5.52 \mathrm{Mg} / \mathrm{km}^{2}$.

The question then has appeared, whether the transformation influenced on SIT-which points the state of threat to natural environment, by changes in financial inputs on the environment protection. It could be interpreted also as the effect of a greater self-governing of the society and the transformation of the approach of authorities to the importance of a environment quality for life standards of the nation. Figure 2 shows the lack of the statistical relationship between SIT and with inputs on the environment protection.

The lack of the dependence is seen also in the high standard deviation $3.489 \mathrm{bln}$. PLN/circa $1.25 \mathrm{bln}$. USD, when the maximum of inputs appeared in $2007-39.7 \mathrm{bln}$. PLN, afterwards they began to fall. It is necessary to notice that into the composition of these inputs among other such things go like expenses on a flood protection, water retention, ecological education and so on, so not bringing direct effects, which would have been joining with the counted SIT.

\section{Conclusions}

In spite of notified limitations, SIT method effectively pictures changes in the state of nature threat in relation to changes of the Poland's economy. This is a useful indicator which permits to apply a possibly objective procedure of the analysis in a dynamic seizure in time and space. It is suitable so for comparative application among different countries. The accomplished analysis showed at

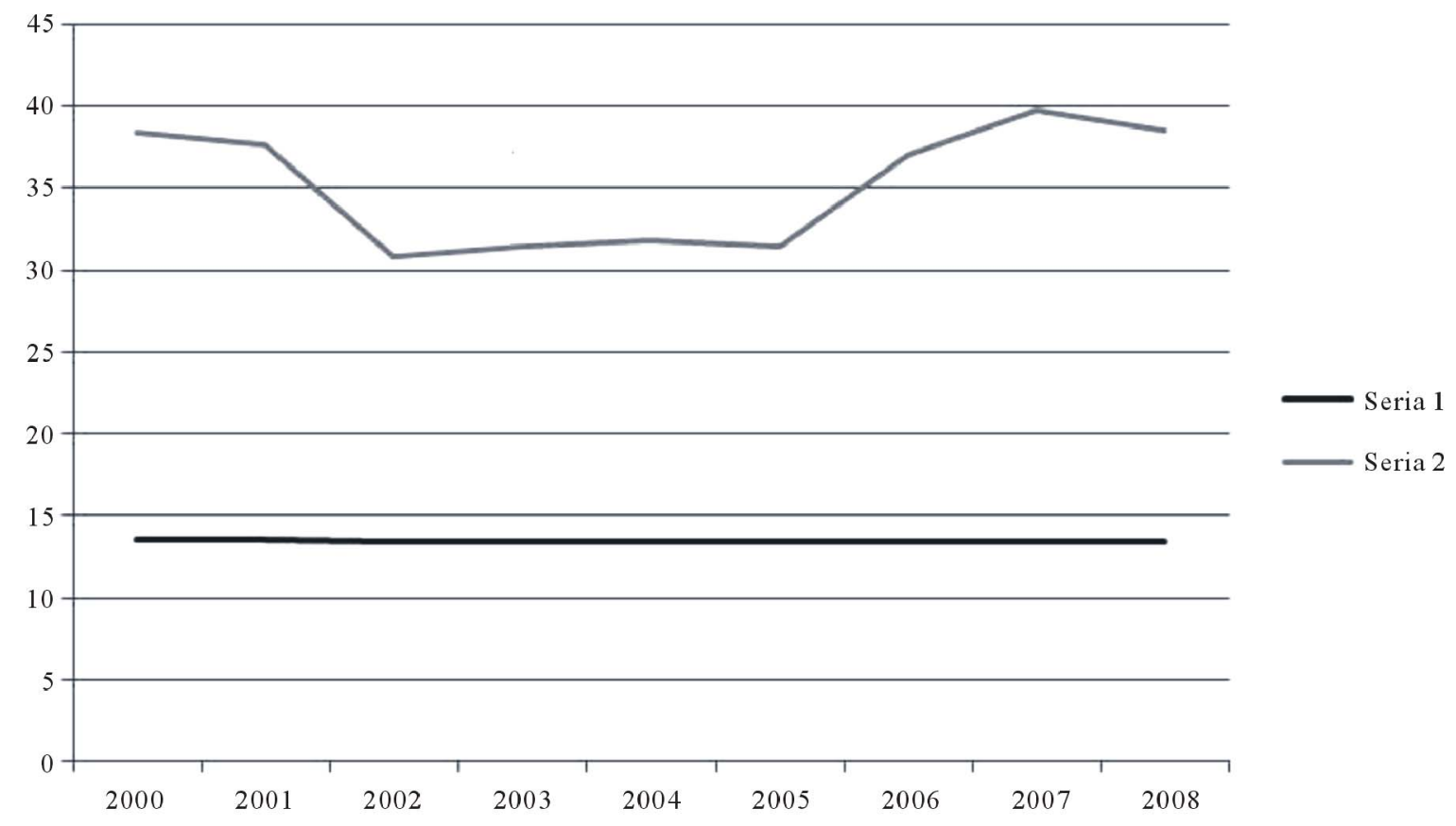

Figure 2. Changes of synthetic index of threat SIT vs. Polish inputs on nature protection during years 2000-2009. Seria 1:Value of SIT in percentage, Seria 2: inputs in bln. PLN. 
the same time a significant fall of the degree of negative anthopic pressure and its stabilization during the recent years.

\section{REFERENCES}

[1] K. R. Mazurski, "Aktualne Problemy Sozologiczne Chin," Kwartalnik Geograficzny, Vol. 4, No. 12, 2000, pp. 5-12.

[2] K. R. Mazurski, "Communism and the Environment," Forum for the Applied Research and Public Policy, Vol. 5, No. 4, 1991, pp. 39-44.

[3] K. R. Mazurski, "Die Transformation Der WirtschaftsUnd Gesellschaftsordnung Polens," Geographie Und Schule, Vol. 93, 1995, pp. 20-30.

[4] J. C. Weaver, "The County as a Spatial Average in Agricultural Geography," Geographical Review, Vol. 46, No. 4, 1956, pp. 536-565. doi:10.2307/212108

[5] K. Doi, "The Industrial Structure of Japanese Prefectures," Proceedings of International Geographical Union. Regional Conference, Japan, August 1957, pp. 310-316.

[6] K. Bielecka, "Metody Określania Elementów Wiodących W Strukturze. Modyfikacja Metody J. C. Weavera," Przeglad Geograficzny, Vol. 43, No. 1-2, 1971, pp.19-36.
[7] K. R. Mazurski, "Stan Środowiska a Warunki Życia w Polsce," Ochrona Środowiska, Vol. 1, No. 38, 1989, pp. 9-12.

[8] K. R. Mazurski, "Ocena Stanu Środowiska-Próba Metody Ilościowej," In: U. Wich, Ed., Gospodarka Przestrzeń Środowisko, Lublin, 1996, pp. 99-107.

[9] Z. Hellwig, “Zastosowanie Metody Taksonomicznej Do Typologicznego Podziału Krajów Ze Względu Na Poziom Ich Rozwoju Oraz Zasoby I Strukturę Wykwalifikowanych Kadr," Przeglad Statystycznych, Vol. 15, No. 4, 1968, pp. 307-327.

[10] K. R. Mazurski, “Ocena Ilościowa Warunków Życia Na Przykładzie Obszarów Ekologicznego Zagrożenia," Prace Karkonoskiego Towarzystwa Naukowego, No. 60, 1992, pp. 41-47.

[11] K. R. Mazurski, "Zagrożenia Środowiska Dolnego Śląska," Oficyna Wydawnicza Sudety, Wrocław, 1994, pp. 218-221.

[12] K. R. Mazurski, "A Quantitative Index of the Threat to the Natural Environment," International Journal of Environmental Studies, Vol. 43, No. 4, 1993, pp. 261-267. doi: 10.1080/00207239308710833

[13] K. R. Mazurski, "Podstawy Sozologii," Oficyna Wydawnicza Sudety, Wrocław, 1998, p. 208. 